\title{
Synthesis and Biological Evaluation of a Highly Constrained Analogue of Methylthioadenosine (MTA)
}

\author{
Gustavo Senra G. de Carvalho ${ }^{1}$, Rafael Mafra de P. Dias ${ }^{1}$, Jean-Louis Fourrey ${ }^{2}$, \\ Vânia L. Silva ${ }^{3}$, Cláudio G. Diniz ${ }^{3}$, Adilson D. da Silva ${ }^{{ }^{*}}$ \\ ${ }^{1}$ Departamento de Química, Instituto de Ciências Exatas (ICE), Universidade Federal de Juiz de Fora, Juiz de Fora-MG, Brasil \\ ${ }^{2}$ Institut de Chimie des Substances Naturelles, Gif-sur-Yvette Cedex, France \\ ${ }^{3}$ Departamento de Parasitologia Microbiologia e Imunologia, Instituto de Ciências Biológicas (ICB), \\ Universidade Federal de Juiz de Fora, Juiz de Fora-MG, Brasil \\ Email: *david.silva@ufjf.edu.br
}

Received June 26, 2012; revised July 27, 2012; accepted August 4, 2012

\begin{abstract}
We describe the synthesis and the antibacterial evaluation $2^{\prime}, N^{3}$-cyclonucleoside 3 analogue of MTA that is characterized by the presence of an additional linkage between the heterocyclic ring and the sugar moiety.
\end{abstract}

Keywords: Synthesis; Biological Evaluation; Antibacterial; Analogue Methylthioadenosine

\section{Introduction}

During the last few years, physicians have been faced with little solutions to care bacterial infections and in particular those due to the advent of resistant bacteria such as MRSA (methicillin-resistant Staphylococcus aureus) [1-3].

Up to now, antibacterial drug discovery has constantly endeavored to propose to the medical community compounds exhibiting a great selectivity towards pathogens without causing any harm to patients [4]. During the recent decades, investigations have bee directed to various microbe specific enzymes that played a key role in the metabolism of pathogens [5-7].

Among others, the case of 5'-methylthioadenosine/Sadenosylmethionine nucleosidase is of utmost importance. Indeed, the recovery of 5'-deoxy-5'-methyl-thioadenosine and $S$-adenosylhomocysteine through the $S$ adenosylmethionine metabolic pathway is crucial to mammals as well as to various microorganisms for the synthesis of polyamines and the methylation of macromolecules (Figure 1) [8-10].

A number of fundamental investigations have disclosed the differences between the metabolic pathways of mammals and those of lower microorganisms such as Escherichia coli, Staphylococcus aureus, Salmonella typhi, Enterococcus faecalis, Mycobacterium tuberculosis, among others. These studies showed that 5'-methyl-

\footnotetext{
${ }^{*}$ Corresponding author.
}

thioadenosine/S-adenosylhomocysteine (MTA/AdoHcy) nucleosidase is specific for many microbes; whereas a corresponding phosphorylase is active in mammals (Figure 1). Accordingly, the dual substrate enzyme, MTA/ AdoHcy nucleosidase, may be an ideal target for the design of specific antimicrobial drugs [11-13].

To date, some nucleoside analogues of MTA, either naturally derived or fully synthetic, acting as inhibitors of MTA/AdoHcy nucleosidase, have been discovered (Figure 2) [13-15].

These nucleoside analogues feature a great variety of chemical structures such as derivatives of acyclic nucleosides, L-nucleosides, carbocyclic nucleosides and many others [16,17].

Herein, we propose the construction of cyclonucleosides that are characterized by the presence of an additional linkage between the heterocyclic ring and the sugar moiety. In this regards, it is noteworthy that cyclonucleosides have been given little attention in view of their application in the medicinal domain [16,17].

Recently, we have defined an efficient access to 2', $\mathrm{N}^{3}$-cyclonucleosides derived from adenosine as shown in Figure 3 [18].

In continuation of this work, we have now synthesized the 2', $N^{3}$-cyclonucleoside 3 analogue of MTA. Our consideration was that if this rigidified MTA analogue could be a substrate of MTA/AdoHcy nucleosidase, it might release a 5-methylthioribose unit having an adenine re- 


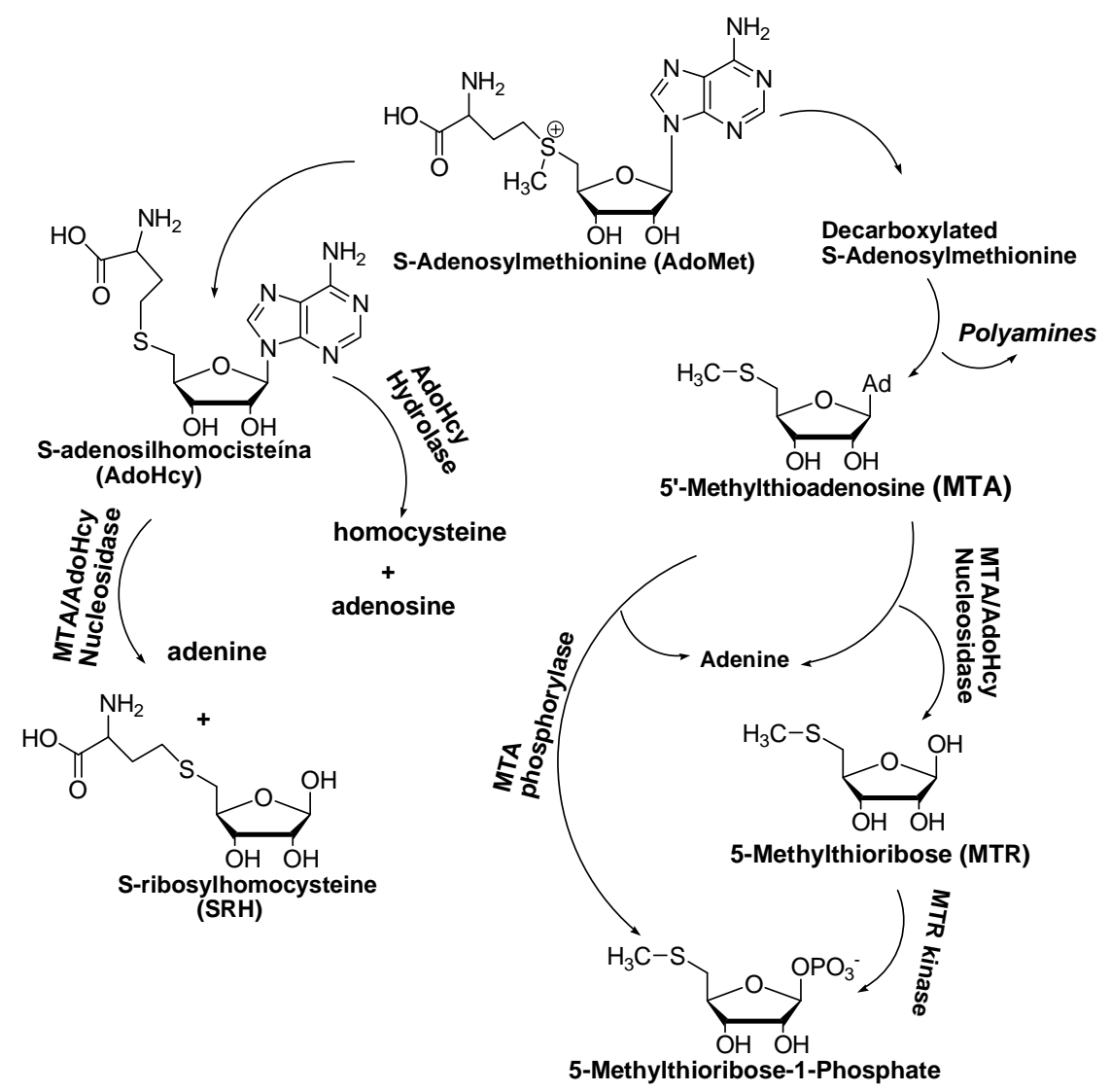

Figure 1. Metabolic pathway of $S$-adenosylmethionine.

maining attached to the ribose moiety, thus depriving the cell of the necessary MTR (Figures 1 and 4).

\section{Experiemtal Section}

\subsection{Chemistry}

General information. All chemicals were purchased as reagent grade and used without further purification, unless otherwise noted. Acetonitrile was distilled over $\mathrm{CaH}_{2}$. DMF was stirred with $\mathrm{Ca}(\mathrm{OH})_{2}$ and distilled under reduced pressure. Reactions were monitored with CCDS and visualized under UV $(254 \mathrm{~nm})$ and/or by exposure at $\mathrm{H}_{2} \mathrm{SO}_{4} 20 \%$ in ethanol. Column chromatography was performed on silica gel $(0.6-0.2 \mathrm{mM}) .{ }^{1} \mathrm{H}$ NMR and ${ }^{13} \mathrm{C}$ NMR spectra were recorded on Bruker $300 \mathrm{MHz}$ spectrometer and/or Bruker $500 \mathrm{MHz}$ spectrometer at $25^{\circ} \mathrm{C}$. 2D NMR was recorded on Bruker $500 \mathrm{MHz}$ spectrometer at $25^{\circ} \mathrm{C}$.

Synthesis.

1,2-O-Isopropylidene-3,5-di-O-(p-toluenesulfonyl)- $\alpha$ D-xylofuranose 8

To a solution 1,2- $O$-isopropylidene- $\alpha$-D-xylofuranose 7 (5.00 g, $26.30 \mathrm{mmol})$ in $\mathrm{CH}_{2} \mathrm{Cl}_{2}(70 \mathrm{~mL})$ were added DMAP (10.90 g, $89.38 \mathrm{mmol})$ and $p$-toluenesulfonyl chloride $(13.00 \mathrm{~g}, 68.35 \mathrm{mmol})$ at $0^{\circ} \mathrm{C}$. The resulting so- lution was stirred $16 \mathrm{~h}$ at RT. Extraction with dichloromethane and evaporation gave a residue that was purified by silica gel column chromatography. Elution with a mixture of hexane/AcOEt (70:30), gave compound 8 as a white solid (9.2 g, $18.45 \mathrm{mmol}, 70 \%) \mathrm{mp} 101.0^{\circ} \mathrm{C}$ $102.0^{\circ} \mathrm{C}$; ${ }^{1} \mathrm{H}$ NMR $\left(300 \mathrm{MHz}, \mathrm{CDCl}_{3}\right) \delta(\mathrm{ppm}), J(\mathrm{~Hz})$ : 1.26 and $1.42\left(2 \mathrm{~s}, 6 \mathrm{H}, 2 \mathrm{CH}_{3}\right.$, Ip), 2.45 and $2.48(2 \mathrm{~s}, 6$ $\mathrm{H}, 2 \mathrm{CH}_{3}$, Ts), 3.99 - 4.05 (dd, $2 \mathrm{H}, \mathrm{H}-5 \mathrm{a}$ and H-5b, $J_{1}=$ 6.5 and $J_{2}=4.0$ ), 4.32 (m, $\left.1 \mathrm{H}, \mathrm{H}-4\right), 4.67$ (d, $1 \mathrm{H}, \mathrm{H}-2, J$ = 3.5), 4.76 (d, $1 \mathrm{H}, \mathrm{H}-3, J=2.7), 5.86$ (d, $1 \mathrm{H}, \mathrm{H}-1$ ), 7.33 - 7.41 (m, $4 \mathrm{H}, \mathrm{CH}, m-\mathrm{Ts}), 7.71$ - 7.80 (m, $4 \mathrm{H}, \mathrm{CH}$, $o$-Ts); ${ }^{13} \mathrm{C}$ NMR (75 MHz, $\left.\mathrm{CDCl}_{3}\right) \delta$ (ppm): 21.8, $21.9(2$ $\left.\mathrm{CH}_{3}, \mathrm{Ts}\right), 26.4$ and $26.7\left(2 \mathrm{CH}_{3}, \mathrm{Ip}\right), 66.1$ (C-5), 76.4 (C-4), 81.4 (C-3), 83.2 (C-2), 104.9 (C-1), 112.9 (C, Ip), 128.2, 130.1, 130.5, 132.3, 132.5, 145.4, 146.1 (C, Ts).

1,2-O-Isopropylidene-5-deoxy-5-thiomethyl-3-O-(p-tol uenesulfonyl)- $\alpha$-D-xylofuranose 9

To a DMF (15 mL) solution of 8 (8.0 g, $16.05 \mathrm{mmol})$, was added sodium methylsulfide ( $1.7 \mathrm{~g}, 24.26 \mathrm{mmol}$ ). The reaction mixture was stirred at reflux for $3 \mathrm{~h}$, filtered, extracted with AcOEt and evaporation gave a residue that was purified by silica gel column chromatography. Elution with hexane/AcOEt (9:1) gave compound 9 (4.8 g, $12.84 \mathrm{mmol}, 80 \%)$ as yellow oil; ${ }^{1} \mathrm{H}$ NMR $(300 \mathrm{MHz}$, $\left.\mathrm{CDCl}_{3}\right) \delta(\mathrm{ppm}), J(\mathrm{~Hz}): 1.22$ and $1.42\left(2 \mathrm{~s}, 6 \mathrm{H}, 2 \mathrm{CH}_{3}\right.$, 

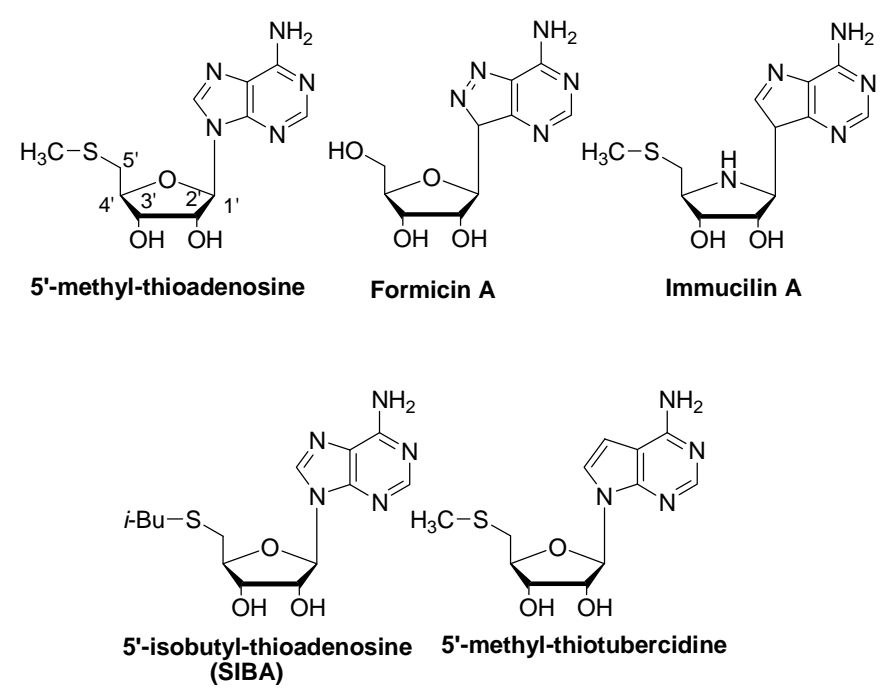

Figure 2. MTA and analogues inhibitors of MTA/AdoHcy nucleosidase.
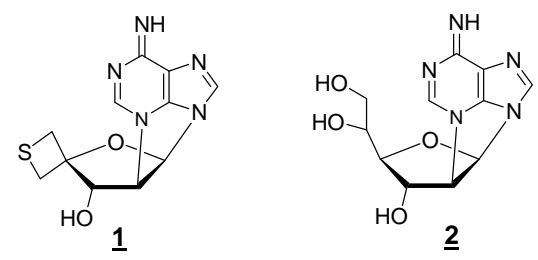

Figure 3. Recent examples of constrained 2', $N^{3}$-cyclonecleosides.

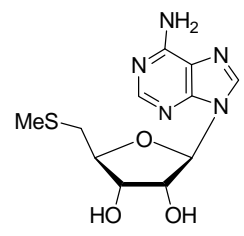

MTA

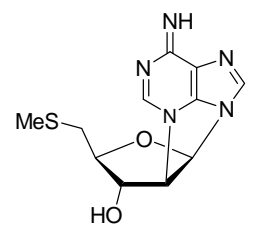

$\underline{3}$
Figure 4. Comparison between MTA and its closer 2', $N^{3}$ cyclonucleoside (3) analogue.

Ip), 2.00 (s, $3 \mathrm{H}, \mathrm{SMe}$ ), 2.39 (s, $3 \mathrm{H}, \mathrm{CH}_{3}, \mathrm{Ts}$ ), 2.43 2.48 (dd, 1 H, H-5a), 3.18 - 3.20 (dd, 1 H, H-5b, $J_{1}=6.0$ and $\left.J_{2}=3.0\right), 4.24-4.29(\mathrm{~m}, 1 \mathrm{H}, \mathrm{H}-4), 4.64$ (d,1H, H-2, $J=3.0$ ), 4.78 (s, $1 \mathrm{H}, \mathrm{H}-3$ ), 5.84 (d, $1 \mathrm{H}, \mathrm{H}-1), 7.31$ (d, 2 $\mathrm{H}, \mathrm{CH}, m$-Ts, $J=8.0$ ), 7.75 (d, $2 \mathrm{H}, \mathrm{CH}, o-\mathrm{Ts}) ;{ }^{13} \mathrm{C}$ NMR $\left(75 \mathrm{MHz}, \mathrm{CDCl}_{3}\right) \delta(\mathrm{ppm}): 16.2\left(\mathrm{CH}_{3}, \mathrm{SMe}\right), 21.6\left(\mathrm{CH}_{3}\right.$, Ts), 26.1 and 26.5 (2 $\mathrm{CH}_{3}$, Ip), 31.2 (C-5), 78.7 (C-4), 82.2 (C-3), 82.9 (C-2), 104.6 (C-1), 112.2 (C, Ip), 127.9 (CH, o-Ts), 130.1 (CH, m-Ts), 132.7 (C-SO $-\mathrm{O}, \mathrm{Ts})$, $145.5\left(\mathrm{C}-\mathrm{CH}_{3}, \mathrm{Ts}\right)$.

1,2-di-O-Acetyl-5-deoxy-5-thiomethyl-3-O-(p-toluenesulfonyl)-D-xylofuranose $\mathbf{1 0}$

Sulfuric acid (95\% - 98\%) (10 drops) was added to a solution of 9 (3.0 g, $8.01 \mathrm{mmol})$ in a mixture of acetic acid $(15 \mathrm{~mL})$ and acetic anhydride $(15 \mathrm{~mL})$ under ice bath. After $4 \mathrm{~h}$ at RT the mixture was added to water.
The solution was neutralized with aq. $\mathrm{NaHCO}_{3}$ and extracted with dichloromethane. The dried organic phase was evaporated and the residue purified by silica gel column chromatography. Elution with a mixture of hexane/AcOEt 80:20 gave the mixture $\mathbf{1 0}$ (1.61 g, 3.85 mmol, 60\%), as a yellow syrup; ${ }^{1} \mathrm{H}$ NMR $(300 \mathrm{MHz}$, $\left.\mathrm{CDCl}_{3}\right) \delta(\mathrm{ppm}), J(\mathrm{~Hz}): 2.05-2.13\left(\mathrm{~m}, 18 \mathrm{H}, 4 \mathrm{CH}_{3}, 2\right.$ Ac and $2 \mathrm{SMe}$ ), 2.47 (sl, $\left.6 \mathrm{H}, 2 \mathrm{CH}_{3}, 2 \mathrm{Ts}\right), 2.72-2.77$ (m, $4 \mathrm{H}, 2 \mathrm{CH}_{2} \mathrm{~S}$ ), 4.48 - 4.55 (m, $\left.2 \mathrm{H}, 2 \mathrm{H}-4\right), 4.96$ (d, 1 $\mathrm{H}, \mathrm{H}-2 \alpha$ ), 5.17 (m, $2 \mathrm{H}, \mathrm{H}-3 \beta$ and $\mathrm{H}-2 \beta$ ), 5.30 (s, $1 \mathrm{H}$, $\mathrm{H}-3 \alpha$ ), 6.02 (s, $1 \mathrm{H}, \mathrm{H}-1 \beta$ ), 6.35 (d, $1 \mathrm{H}, \mathrm{H}-1 \alpha$ ), 7.37-7.39 (m, $4 \mathrm{H}, \mathrm{CH}, m-\mathrm{Ts}), 7.84$ - 7.86 (m, $4 \mathrm{H}, \mathrm{CH}$, $o$-Ts); $\left.{ }^{13} \mathrm{C} \mathrm{NMR} \mathrm{(75MHz,} \mathrm{CDCl}_{3}\right) \delta(\mathrm{ppm}): 16.4,16.9$, 20.1, 20.6, 20.7, 20.9, 21.1 and $21.8\left(\mathrm{CH}_{3}\right.$, Ac, SMe, $\mathrm{CH}_{3}$, Ts), 33.1 and 33.3 (2 C-5), 76.0, 78.6, 78.9, 79.9, 80.9 and 82.3 (2 C-2, 2 C-3 and 2 C-4), 93.0 and 98.7 (2 C-1), 128.1 and 128.2 (2 CH, o-Ts), 130.1 (CH, m-Ts), 133.0

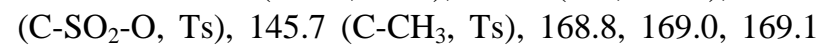
and 169.3 (4 $\mathrm{C}=\mathrm{O}, \mathrm{Ac})$.

$N^{6}$-Benzoyl-9-[2'-O-acetyl-5'-deoxy-5'-thiomethyl-3'$O$-(p-toluenesulfonyl)- $\beta$-D-xylofuranosyl]-adenine 11

A suspension of $N^{6}$-benzoyladenine (300 mg, 1.25 mmol) in HMDS $(4.0 \mathrm{~mL})$ and $0.5 \mathrm{~mL}$ of TMSCl was refluxed for $18 \mathrm{~h}$. The reaction was cooled and evapo0 rated to dryness under vacuum. Then 10 (500 mg, 1.20 mmol), in anhydrous acetonitrile $(5 \mathrm{~mL})$ containing a catalytic amount of TMSOTf $(0.2 \mathrm{~mL}, 1.10 \mathrm{mmol})$, was added to the silylated $6-N^{6}$-benzoyladenine under an argon atmosphere.

After stirring for $24 \mathrm{~h}$, TLC analysis (AcOEt) showed conversion of the starting carbohydrate into a lowerrunning product. The reaction mixture was quenched with a saturated solution of $\mathrm{NH}_{4} \mathrm{Cl}(3 \mathrm{~mL})$ and stirred for $30 \mathrm{~min}$, diluted with ether $(30 \mathrm{~mL})$ and poured in aq. $\mathrm{NaHCO}_{3}(5 \mathrm{~mL})$. 
The organic phase was washed with water $(5 \mathrm{~mL})$, dried, filtered and evaporated. The reaction product was purified by silica gel column chromatography. Elution with a mixture of hexane/AcOEt 9:1, to give $180 \mathrm{mg}$ of compound 11, as a brown amorphous solid 40\% yield; mp: $107.1^{\circ} \mathrm{C}-109.3^{\circ} \mathrm{C} ;{ }^{1} \mathrm{H}$ NMR (300 MHz, $\left.\mathrm{CDCl}_{3}\right) \delta$ (ppm), $J(\mathrm{~Hz}): 2.16$ and 2.17 (m, $6 \mathrm{H}, \mathrm{CH}_{3}$, Ts and SMe), 2.38 (s, $3 \mathrm{H}, \mathrm{CH}_{3}$, Ts), 2.81 - 2.97 (qd, $2 \mathrm{H}, \mathrm{H}-5$ 'a and H-5'b, $J_{1}=13.0, J_{2}=6.0$ ), $4.50-4.55$ (m, 1 H, H-4'), 5.15 (d, 1 H, H-2', $J=3.7$ ), 5.38 (s, 1 H, H-3'), 6.20 (d, 1 H, H-1'), 7.23 (d, 2 H, CH, $m$-Ts, $J=7.0), 7.53$ (t, 2 H, $m$-Bz, $J=7.0$ ), 7.57-7.60 (m, $1 \mathrm{H}, \mathrm{CH}, p-\mathrm{Bz}), 7.69$ (d, 2 H, CH, $o$-Ts, $J=8.0$ ), 8.05 (d, $2 \mathrm{H}, o-\mathrm{Bz}, J=7.0$ ), 8.20 (s, $1 \mathrm{H}, \mathrm{H}-2$ ), 8.67 (s, $1 \mathrm{H}, \mathrm{H}-8), 9.35$ (bs, $1 \mathrm{H}, \mathrm{N}-H$ ); ${ }^{13} \mathrm{C}$ NMR (750MHz, $\left.\mathrm{CDCl}_{3}\right) \delta(\mathrm{ppm}): 16.8(\mathrm{SMe}), 20.8\left(\mathrm{CH}_{3}\right.$, Ac), 21.9 ( $\mathrm{CH}_{3}$, Ts), 31.9 (C-5'), 79.2 (C-4'), 80.6 (C-2'), 82.2 (C-3’), 87.9 (C-1'), 122.8 (C-5), 127.9 and 128.1 (CH, $m-\mathrm{Bz}$ and $\mathrm{CH}, o-\mathrm{Ts}), 129.1$ (CH, $o-\mathrm{Bz}), 130.1$ and 130.2 (CH, $m$-Ts), 132.6 (C $-\mathrm{C}(=\mathrm{O})-\mathrm{Ph}, \mathrm{Bz}), 133.1$ (CH,

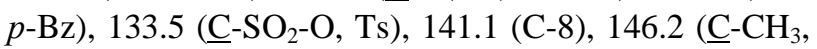
Ts), 149.4 (C-4), 151.3 (C-6), 152.7 (C-2), 165.1 (C=O, $\mathrm{Bz}), 168.8$ (C=O, Ac). ESI-MS: [M + Na ${ }^{+}$620.2; Anal. Calcd. for $\mathrm{C}_{27} \mathrm{H}_{27} \mathrm{~N}_{5} \mathrm{O}_{7} \mathrm{~S}_{2} \mathrm{Na}$.

2', $N^{3}$-cyclo-9-[5'-deoxy-5'-S-methyl- $\beta$-D-arabinofuranosyl]-adenine 3

A solution of 11 (200 mg, $0.34 \mathrm{mmol}$ ) in a mixture of $\mathrm{MeOH}(6 \mathrm{~mL})$ and $25 \% \mathrm{NH}_{4} \mathrm{OH}$ in water $(3 \mathrm{~mL})$ was stirred at room temperature for $18 \mathrm{~h}$. The solution was evaporated to dryness. The residue was purified by silica gel column chromatography. Elution with a mixture of $\mathrm{CH}_{2} \mathrm{Cl}_{2} / \mathrm{MeOH} 70: 30$ gave $83.40 \mathrm{mg}$ of $3,89.23 \%$ yield; ${ }^{1} \mathrm{H}$ NMR (500 MHz, $\left.\mathrm{CDCl}_{3}\right) \delta(\mathrm{ppm}): J(\mathrm{~Hz}): 2.09$ (s, 3 H, SMe), 2.68 - 2.80 (m, 2 H, H-5'a and H-5’b), 4.19 (s, 1 H, H-2'), 4.45 - 4.47 (m, 2 H, H-3' and H-4'), 5.86 (sl, $2 \mathrm{H}, \mathrm{O}-H$ and $\mathrm{N}-H$ ), 6.17 (s, $1 \mathrm{H}, \mathrm{H}-1^{\prime}$ ), 7.96 (s, $1 \mathrm{H}$, $\mathrm{H}-8), 8.35$ (s, $1 \mathrm{H}, \mathrm{H}-2)$; ${ }^{13} \mathrm{C}$ NMR (100 MHz, $\left.\mathrm{CDCl}_{3}\right) \delta$ (ppm): 16.3 (SMe), 35.3 (C-5'), 58.0 (C-2'), 59.9 (C-3’), 79.9 (C-4'), 84.5 (C-1'), 120.5 (C-5), 140.1 (C-8), 149.5 (C-4), 153.3 (C-2), 155.8 (C-6); ESI-MS: $[\mathrm{M}+\mathrm{Na}]^{+}$ 302.0; Anal. Calcd. for $\mathrm{C}_{11} \mathrm{H}_{13} \mathrm{~N}_{5} \mathrm{O}_{2} \mathrm{SNa}$ (302.1). HMRS: $[\mathrm{M}+\mathrm{Na}]^{+}$302.0694; Anal. Calcd. for $\mathrm{C}_{11} \mathrm{H}_{13} \mathrm{~N}_{5} \mathrm{O}_{2} \mathrm{SNa}$ (302.0682).

\subsection{Biology}

\section{Antibacterial activity.}

As Broth Dilution Method [19] recommended by the Clinical Laboratory Standard Institute, the antibacterial activity of the compound in question was investigated in vitro against eight ATCC strains (American Type Culture Collection): 4 Gram negative (Klebsiella pneumoniae ATCC 13866, Salmonella typhi ATCC 19430, Escherichia coli ATCC 11229, Pseudomonas aeruginosa ATCC 27853 and 4 Gram positive (Staphylococcus epidermidis
ATCC 12228, Staphylococcus aureus ATCC 25923, Micrococcus lentus ATCC 10240, and Enterococcus faecalis ATCC 51299).

Microorganisms were cultured aerobically in broth Triptych Soy Agar (Difco) at $35.5^{\circ} \mathrm{C}$ for $24 \mathrm{~h}$ for inoculation, each was adjusted to $0.5 \mathrm{McF}$ arland turbidity (1.5 $\times 108 \mathrm{CFU} / \mathrm{ml}$ ) with sterile saline ( $\mathrm{NaCl} 0.85 \%)$. The compound tested 3 was dissolved in DMSO for the purchase of two different concentration (1.79 mM and 11.81 $\mathrm{mM}$ ) and solutions were diluted with Mueller Hinton Broth (Difco) to obtain concentrations $0.023 \mathrm{mM}$ and $1.833 \mathrm{mM}$ in a final volume of $3 \mathrm{~mL}$. The tubes were inoculated with $100 \mathrm{mM}$ of bacterial culture and incubated aerobically at $35.5^{\circ} \mathrm{C} / 24 \mathrm{~h}$. The experiment was done in triplicate. Control experiments were performed using only DMSO.

\section{Results and Discussion}

\subsection{Chemistry}

Synthesis and characterization of 2', $N^{3}$-cyclo-5'-deoxy5'-methyl-thioadenosine 3 (Scheme 1)

First, diisopropylidene glucose was selectively hydrolyzed to give the known triol 5 [18]. After an oxidative cleavage step, the resulting aldehyde $\mathbf{6}$ was reduced with $\mathrm{NaBH}_{4}$ to give diol 7 [20]. A solution of this compound in dichloromethane was treated with 3 eq. of $p$-toluenesulphonyl chloride in the presence of DMAP to provide the ditosylated compound $\mathbf{8}$.

A subsequent treatment of compound $\mathbf{8}$ with sodium methylsulfide in DMF at $120^{\circ} \mathrm{C}$ led to derivative $\mathbf{9}$. The spectral data (NMR) confirmed that compound $\mathbf{9}$ was monotosylated in agreement with the presence of one methyl singlet at $\delta 2.39 \mathrm{ppm}$, whereas the methyl singlet at $\delta 2.00 \mathrm{ppm}$ was due to the presence of the MeS-group at the $\mathrm{C}-5$ position of ribose that is confirmed by viewing the new pattern of the signals ascribed to the methylene at C-5.

In the next step, compound $\mathbf{9}$ was engaged in the necessary transformations to continue with the introduction of $N^{6}$-benzoyladenine at the anomeric position using the Vorbrügen's method. Thus, removal of the isopropylidene group and in situ acetylation of the resulting diol was accomplished using a mixture of acetic anhydride/ acetic acid containing a catalytic amount of concentrated sulfuric acid. This procedure furnished the diacetate $\mathbf{1 0}$ as a $1: 1$ mixture of $\alpha / \beta$ diastereoisomers.

Then, the mixture $\mathbf{1 0}$ was combined with a previously silylated $N^{6}$-benzoyladenine in the presence a TMS-triflate in acetonitrile under argon atmosphere to provide nucleoside 11. Due to the formation of an intermediate acyloxonium, there is no need to separate the $\alpha / \beta$ diastereoisomers of mixture 10, the final product being the $\beta$-isomer, exclusively. The spectral data (NMR) of the 

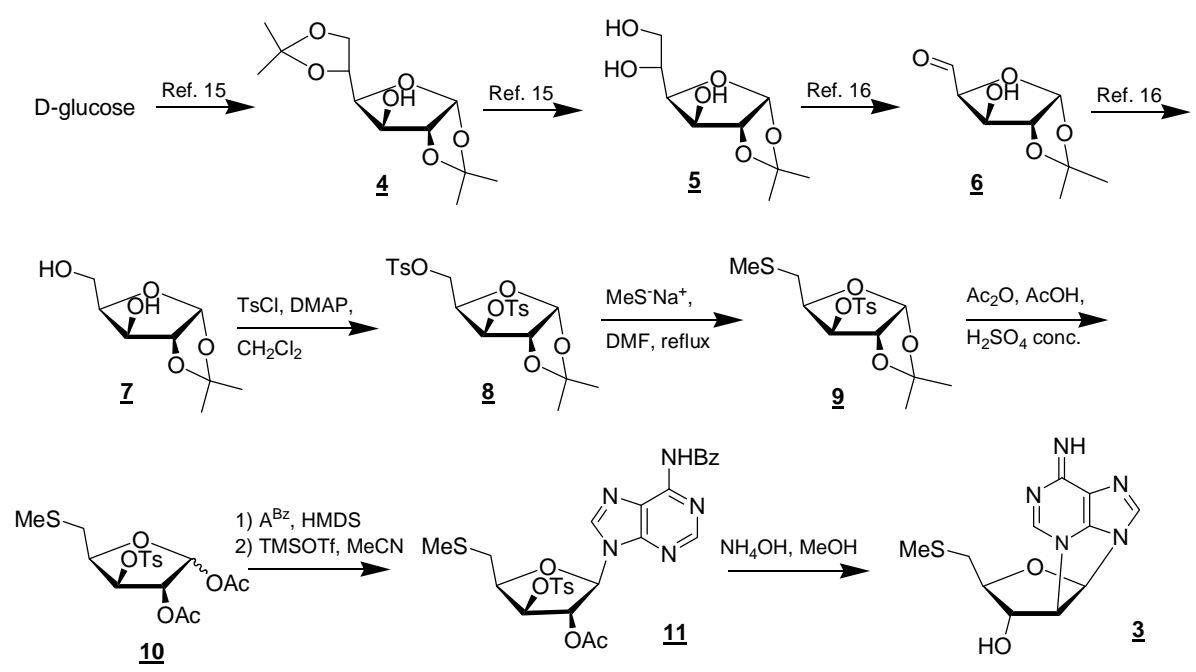

Scheme 1. Reaction pathway for the synthesis of the 2', $N^{3}$-cyclonucleoside (3) analogue of MTA.

protected nucleoside $\mathbf{1 1}$ are in agreement with the proposed structure as shown by the presence of the $\mathrm{H}-1$ ' sugar doublet signal at $\delta 6.20 \mathrm{ppm}$ and the $\mathrm{H}-2$ singlet signal of adenine at $\delta 8.20 \mathrm{ppm}$.

Finally, as expected from our previous report, the treatment of precursor $\mathbf{1 1}$ in a solution of $\mathrm{NH}_{4} \mathrm{OH} / \mathrm{MeOH}$ $1: 3$ at room temperature gave rise to a cyclization reaction together with adenine debenzoylation leading to compound 3 in $60 \%$ yield. The structure of cyclonucleoside 3 was confirmed by the interpretation of its MS and NMR data, including HMBC and NOESY spectra (Table 1).

All compounds have been characterized by IR and NMR spectroscopy. When needed, we utilized 2D NMR spectroscopy.

\subsection{Bioassays}

Antibacterial activity.

The antibacterial activity of $2^{\prime}, N^{3}$-cyclo MTA 3 was further evaluated in vitro against eight bacteria, in which four Gram positive (Staphylococcus aureus ATCC 25923, Staphylococcus epidermidis ATCC 12228, Enterococcus faecalis ATCC 51299 and Micrococcus lentus ATCC 10240) and four Gram negatives (Escherichia coli ATCC 11229, Salmonella typhi ATCC 19430, Pseudomonas aeruginosa ATCC 27853 and Klebisiella pneumonae ATCC 13866). Overall, the MIC ranged between 0.023 $\mathrm{mM}$ and $1.833 \mathrm{mM}$.

Compound 3 showed activity at concentrations above $1.0 \mathrm{mM}$ for all tested bacteria strains, minimal inhibitory concentrations were not determined because the compound precipitated in the culture media above $1.0 \mathrm{mM}$.

\section{Conclusion}

Compound 2', $N^{3}$-cyclonucleoside (3) analogue of MTA
Table 1. Data of ${ }^{1} \mathrm{H},{ }^{13} \mathrm{C}, \mathrm{HMBC}$ and NOESY for compound 3.

\begin{tabular}{|c|c|c|c|c|}
\hline Position & ${ }^{13} \mathrm{C} \delta(3)$ & $\begin{array}{c}{ }^{1} \mathrm{H} \delta(3) \\
\text { (mult, } J \text { in } \mathrm{Hz} \text { ) }\end{array}$ & $\begin{array}{c}\mathrm{HMBC} \\
{ }^{1} \mathrm{H}^{-13} \mathrm{C}(3)\end{array}$ & $\begin{array}{c}\text { NOESY } \\
{ }^{1} \mathrm{H}-{ }^{1} \mathrm{H}(3)\end{array}$ \\
\hline 2 & 153.3 & $8.35(\mathrm{~s} ; 1 \mathrm{H})$ & 4 and 6 & - \\
\hline 4 & 149.5 & - & - & - \\
\hline 5 & 120.5 & - & - & - \\
\hline 6 & 155.8 & - & - & - \\
\hline 8 & 140.1 & $7.96(\mathrm{~s} ; 1 \mathrm{H})$ & 4 and 5 & $1^{\prime}$ \\
\hline $1^{\prime}$ & 84.5 & 6.17 (d; 1H; 5.6) & 3', 4', 8 and 4 & 4 ' and 8 \\
\hline 2' & 58.0 & 4.19 (d; 1H; 5.6) & $4^{\prime}$ & $5 ’ b$ \\
\hline 3 , & 59.9 & $4.45-4.47(\mathrm{~m} ; 2 \mathrm{H})$ & 1' & 5'a and 5'b \\
\hline 4 ' & 80.0 & 4.45 - $4.47(\mathrm{~m} ; 2 \mathrm{H})$ & $2^{\prime}$ & 1', 5'a and 5'b \\
\hline 5 ' & 35.3 & $\begin{array}{c}3.00 \\
\text { (dd; 2H; 2.1; 9.6) }\end{array}$ & 3'; 4' and MeS & $\begin{array}{c}\text { 2', 3', 4' and } \\
\text { MeS }\end{array}$ \\
\hline
\end{tabular}

${ }^{\mathrm{a}}$ The experiment was performed at $500 \mathrm{MHz}$ for ${ }^{1} \mathrm{H}$ and $100 \mathrm{MHz}$ for ${ }^{13} \mathrm{C}$ in $\mathrm{CDCl}_{3}$ and TMS as internal $(\delta 0.00 \mathrm{ppm})$.

belonging to the little explored class of adenine $2^{\prime}, N^{3}$ cyclonucleosides has been synthesized. Preliminary biological investigations showed the compound to manifest a promising anti-bacterial activity against a number of representative bacterial strains. These results are promising since the constrained nucleoside appeared to be nontoxic in human MRC- 5 cells.

\section{Acknowledgements}

This work was financially supported by FAPEMIG, CNPq and UFJF.

\section{REFERENCES}

[1] E. Tacconelli, G. De Angelis, M. A. Cataldo, E. Pozzi and 
R. Cauda, "Does Antibiotic Exposure Increase the Risk of Methicillin-Resistant Staphylococcus Aureus (MRSA) Isolation? A Systematic Review and Meta-Analysis," Journal of Antimicrobial Chemotherapy, Vol. 61, No. 1, 2008, pp. 26-38. doi:10.1093/jac/dkm416

[2] D. M. Drekonja, L. M. Traynor, D. Decarolis, K. B. Crossley and J. R. Johnson, "Treatment of Non-LifeThreatening Methicillin-Resistant Staphylococcus Aureus Infections with Alternative Antimicrobial Agents: A 2-Year Retrospective Review,” Diagnostic Microbiology and Infectious Disease, Vol. 63, No. 2, 2009, pp. 201-207. doi:10.1016/j.diagmicrobio.2008.10.001

[3] H. W. Boucher, G. H. Talbot, J. S. Bradley, J. E. Edwards Jr., D. Gilbert, L. B. Rice, M. Scheld, B. Spellberg and J. Bartlet, "Bad Bugs, No Drugs: No ESKAPE! An Update from the Infectious Diseases Society of America," Clinical Infectious Disease, Vol. 48, No. 1, 2009, pp. 1-12. doi:10.1086/595011

[4] M. K. Riscoe, A. J. Ferro and J. H. Fitchen, "Methionine Recycling as a Target for Antiprotozoal Drug Development," Parasitology Today, Vol. 5, No. 10, 1989, pp. 330-333. doi:10.1016/0169-4758(89)90128-2

[5] M. P. Barrett, J. C. Mottram and G. H. Coombs, "Recent Advances in Identifying and Validating Drug Targets in Trypanosomes and Leishmanias," Trends in Microbiology, Vol. 7, No. 2, 1999, pp. 82-88. doi:10.1016/S0966-842X(98)01433-4

[6] P. A. Michels, F. Bringaud, M. Herman and V. Hannaert, "Metabolic Functions of Glycosomes in Trypanosomatids,” Biochimica et Biophysica Acta, Vol. 1763, No. 12, 2006, pp. 1463-1477. doi:10.1016/j.bbamcr.2006.08.019

[7] J. F. Barrett, J. A. Sutcliffe and T. D. Gootz, "In Vitro Assays Used to Measure the Activity of Topoisomerases," Antimicrobial Agents and Chemotherapy, Vol. 34, No. 1, 1990, pp. 1-7. doi:10.1128/AAC.34.1.1

[8] M. H. El Kouni, "Potential Chemotherapeutic Targets in the Purine Metabolism of Parasites,” Pharmacolology \& Therapeutics, Vol. 99, No. 3, 2003, pp. 283-309. doi:10.1016/S0163-7258(03)00071-8

[9] S. Muller, E. Liebau, R. D. Walter and R. L. KrauthSiegel, "Thiol-Based Redox Metabolism of Protozoan Parasites," Trends in Parasitology, Vol. 19, No. 7, 2003, pp. 320-328. doi:10.1016/S1471-4922(03)00141-7

[10] C. H. Miller and J. A. Duerre, "S-Ribosylhomocysteine Cleavage Enzyme from Escherichia coli," Journal of Biological Chemistry, Vol. 243, No. 1, 1968, pp. 92-97.

[11] W. A. M. Loenen, " $S$-Adenosylmethionine: Jack of All Trades and Master of Everything?” Biochemical Society Transactions, Vol. 34, No. 2, 2006, pp. 330-333.
doi:10.1042/BST20060330

[12] M. Fontecave, M. Atta and E. Mulliez, "S-Adenosylmethionine: Nothing Goes to Waste," Trends in Biochemical Science, Vol. 29, No. 5, 2004, pp. 243-249. doi:10.1016/j.tibs.2004.03.007

[13] J. E. Lee, E. C. Settembre, K. A. Cornell, M. K. Riscoe, J. R. Sufrin, S. E. Ealick and P. L. Howell, "Structural Comparison of MTA Phosphorylase and MTA/AdoHcy Nucleosidase Explains Substrate Preferences and Identifies Regions Exploitable for Inhibitor Design,” Biochemistry, Vol. 43, No. 18, 2004, pp. 5159-5169.

[14] M. E. Tedder, Z. Nie, S. Margosiak, S. Chu, V. A. Feher, R. Almassy, K. Appelt and K. M. Yager, "StructureBased Design, Synthesis, and Antimicrobial Activity of Purine Derived SAH/MTA Nucleosidase Inhibitors," Bioorganic and Medicinal Chemistry, Vol. 14, No. 12, 2004, pp. 3165-3168. doi:10.1016/j.bmcl.2004.04.006

[15] V. Singh, G. B. Evans, D. H. Lenz, J. M. Mason, K. Clinch, S. Mee, G. F. Painter, P. C. Tyler, R. H. Furneaux, J. E. Lee, P. L. Howell and V. L. Schramm, "Femtomolar Transition State Analogue inhibitors of 5'-Methylthioadenosine/S-Adenosylhomocysteine Nucleosidase from $E S$ cherichia coli," Journal of Biological Chemistry, Vol. 280, No. 18, 2005, pp. 18265-18273. doi:10.1074/jbc.M414472200

[16] A. Mieczkowski, V. Roy and L. A. Agrofoglio, "Preparation of Cyclonucleosides," Chemical Reviews, Vol. 110, No. 4, 2010, pp. 1828-1856.

[17] A. Mieczkowski and L. A. Agrofoglio, "Potential and Perspectives of Cyclonucleosides," Current Medicinal Chemistry, Vol. 17, No. 15, 2010, pp. 1527-1549. doi:10.2174/092986710790979962

[18] G. S. G. de Carvalho, J.-L. Fourrey, R. H. Dodd and A. D. da Silva, "Synthesis of a 4',4'-Spirothietane-2', $N^{3}$-cycloadenosine as a Highly Constrained Analogue of 5'-Deoxy-5'-methylthioadenosine (MTA)," Tetrahedron Letters, Vol. 50, No. 4, 2009, pp. 463-466. doi:10.1016/j.tetlet.2008.11.039

[19] D. R. Stalons and C. Thornsberry, "Broth-Dilution Method for Determining the Antibiotic Susceptibility of Anaerobic Bacteria," Antimicrobial Agents and Chemotherapy, Vol. 7, No. 1, 1975, pp. 15-21. doi:10.1128/AAC.7.1.15

[20] I. Zlatev, J.-L. Vasseur and F. Morvan, "Deoxygenation of 5-O-benzoyl-1,2-isopropylidene-3-O-imidazolylthiocarbonyl- $\alpha$-D-xylofuranose Using Dimethyl Phosphite: An Efficient Alternate Method towards a 3'-Deoxynucleoside Glycosyl Donor," Tetrahedron Letters, Vol. 49, No. 20, 2008, pp. 3288-3290. doi:10.1016/j.tetlet.2008.03.079 